\title{
Anecdotally Queer:The Then and There of My Prairie Home
}

\begin{abstract}
This paper considers two contested spatial and temporal thresholds in relation to queer and trans life: the threshold between urban and rural, and the threshold between past and future. Through a discursive analysis of Chelsea McMullan's 2013 documentary on trans singer-songwriter Rae Spoon My Prairie Home, I explore the queer possibilities situated between these thresholds and provide an opportunity to rethink our assumptions about queer and trans identities in rural spaces. Drawing together recent queer theory that reconceptualizes queerness as undecidability, Meghan Morris's theory of anecdotal identity and Michel de Certeau's philosophy of spatial stories, I argue that My Prairie Home offers us an anecdotal vision of queer rural life. The rural becomes queer and thus becomes an undecidable space that we cross on our way home. Contrary to the common perception that the urban is the only spatial configuration in which queers can flourish, I rescue the rural as a necessary approach to thinking queer life.
\end{abstract}

KEYWORDS: space and time; rural; anecdote; queer; transgender; futures

○ִ

Rural spaces are queer spaces. They have to be, if only for the simple fact that many queers call rural spaces home. This is a fact that many of us are prone to forgetting, with what Jack Halberstam calls "metronormativity" - that is, the narrative of queer migration from country to city, from rural homophobia to urban liberation-dominating and monopolizing the discursive space of queer life (Halberstam 2005: 36). This is not to say that rural spaces are necessarily marginalized spaces in relation to dominantly queer urban spaces, even though they do not hold enough power to be considered dominant. Rural spaces are more incidental than marginal, or better, anecdotal. Rural spaces are held together by anecdotes. Each space, and each object within a space, has its own story, its own narration, its own anecdote. The collection of these anecdotes - these unpredictably common stories and ways of narrating everyday life-provides the logic for the space. The queerness of everyday life, of 
rural spaces and of anecdotes, is not evident to us until we are confronted with the possibility that we cannot determine or predict what may happen.

In what follows I attempt to theorize this unpredictable queerness of the everyday rural life in the documentary My Prairie Home (McMullan 2013). A musical documentary on prairie rurality, the film follows Rae Spoon, a trans singer-songwriter who grew up queer on the Canadian Prairies. The film traces Spoon's tour across rural Alberta and Saskatchewan and is interspersed with anecdotes, encounters with their past, and musical interludes staged for the camera. As Spoon travels across the Canadian Prairies, I too travel through the documentary and connect it to theories and stories of space, place, and (queer) identity to create not just a place of concrete claims and stable logic but a space of unpredictable trajectories where ideas can meet and break apart in surprising ways. Drawing on Erin J. Rand's reconceptualization of queer as undecidable, I suggest that what makes the rural — and the rural home- queer is its very spatial and temporal undecidability. This undecideability, I argue, is held together by a very specific spatial story: the anecdote. The rural is an anecdotal space: a queerly undecideable space that erupts and emerges in unpredictable ways. In other words, rural spaces are anecdotally queer. Contrary to dominant narratives that see the rural as destructive for queers and the city as the only possible spatial configuration allowing queers to flourish and that queers can safely call home, I argue that My Prairie Home shows us the queer possibility to be found in the temporal and spatial ambiguity of rural spaces.

\section{Crossing the Frontier}

"Every story is a travel story—a spatial practice" (de Certeau 1984: 115).

Every story is a way of doing space. Indeed, space is not a thing that is but a thing that can be done. For de Certeau, "space is a practiced place" (117 emphasis original). A place is "an instantaneous configuration of positions. It implies an indication of stability" (117). A place is where things exist alongside each other in determined relations: a building next to a road, next to a sidewalk, built over a sewer system, and so on. In a place, de Certeau says, "the elements taken into consideration are beside one another, each situated in its own 'proper' and distinct location, a location it defines" (117 emphasis original). A place is a configuration of things that exist and can be seen and pointed at (119). It is thus not limited simply to geography or architecture, but importantly can refer to texts, ideas, and signs. Calgary, Alberta is thus a place, as is the building you may be reading this in, that film you saw yesterday, or those books you are currently reading. Places are things that exist in defined relations in the world. They are stable. They do not move.

If a space is the putting into practice of place, then a space is a place in motion. Space is the practice of moving through place and its stable configuration of objects, or, as Doreen Massey puts it, "[s]pace is a configuration [...] of a multiplicity of trajectories" (2000: 225). It is the effect of situating a place in a particular temporality 
as the collision of a multitude of "conflictual programs or contractual proximities" (de Certeau 1984: 117). If place is a configuration of objects, then space is a configuration of movements. Drawing an analogy to language, de Certeau explains the relationship between space and place as a relationship between a word and a word spoken:

On this view, in relation to place, space is like a word when it is spoken; that is, when it is caught in the ambiguity of an actualization, transformed into a term dependent upon many different conventions, situated as the act of a present (or of a time), and modified by the transformations caused by successive contexts. In contradistinction to the place, it has none of the univocity or stability of a "proper." (117)

Space is the unpredictability of navigating a place. Erin J. Rand calls this the "gap" of undecidability between the intended purpose behind a street, a building, a park bench, and the ways in which people use and engage with them (Rand 2014:24). The city does not become a space until people walk through it, and walk through it in their own particular fashion. The analogy to language is key for de Certeau because it is the process of narration in the everyday sense that allows for spaces: "Stories thus carry out a labor that constantly transforms places into spaces or spaces into places" (1984: 118). What makes a place a space is the fact of narration, of walking through a space and indicating that after you pass the bridge you make a left and follow the road until you reach the conservatory. This speaking of the configuration of the objects and wandering through it is what makes space into a practiced place.

This transformation of places into spaces is what de Certeau calls "operations of marking out boundaries" (122). By intervening into a place, spatial practices mark out its own boundaries, drawing together a bricolage of disparate parts "in a makeshift fashion" (122). We pull part of the road together with the conservatory, which, when told as a story, becomes not just a space but this space. Indeed, it is the "partition of space" that provides the structure of the space.

Everything refers to this differentiation which makes possible the isolation and interplay of distinct spaces. From the distinction that separates a subject from its exteriority to the distinctions that localize object, from the home (constituted on the basis of the wall) to the journey (constituted on the basis of a geographical "elsewhere" or cosmological "beyond"), from the functioning of the urban network to that rural landscape, there is no spatiality that is not organized by the determination of frontiers (123).

The frontier is what demarcates and delimits a space. The frontier is what marks this space from that space. Of interest to me here is specifically the frontier between the urban network and the rural landscape and the ways in which stories mark the frontier between them. To think of the urban and rural in terms of their frontier 
is to think of the point where they meet. The frontier is a paradox: "[T]he points of differentiation between two bodies are also their common points" (127). When the urban and rural touch, as they do spatially at the city limits, what they have in common is their mutual frontier marked by their difference: on the one side, a network of urban life; on the other, the vast expanses of rurality.

As a paradox, the frontier is an undecidable space, a space between spaces that is only present through its very absence. The moment we attempt to make the frontier present, to mark it as a place, it is no longer a space and thus no longer a frontier. For just as the frontier marks the boundaries between spaces, it is also the bridge that allows us to cross between them. The bridge and the frontier are almost inseparable for de Certeau. Space, as a narrative practice, "'turns' the frontier into a crossing [...] into a bridge" (128). The frontier can be crossed, making the boundaries between spaces porous, and the spaces themselves ambiguous and indistinguishable. Thus the very practice that delimits spaces, that sets the boundaries between inside and outside, between urban and rural, is the very practice that, as de Certeau says, "opens the inside to its other" and upsets the very possibility of a clearly delimited and demarcated space (129). If the frontier is to remain a space, and not a place, it has to be understood then, not as that which cannot be crossed, but that as which must be crossed.

The frontier, then, cannot belong to either the urban or the rural. Yet it must be crossed or else it ceases to be a frontier. However, this space that is neither urban nor rural, neither inside nor outside, is less like Homi Bhabha's third space, which is an uncanny space where the foreign and the familiar converge, and more of a space marked entirely by its recession (Morley 2000: 211). Paradoxically, this both supports and undercuts Frederick Jackson Turner's frontier thesis. Simply put, the frontier thesis argued, "[T] he preservation of a wild frontier was essential for American democracy" (Woods 2011: 255). This "wild frontier" was an undiscovered place separate from urban settlements-a myth in Turner's thesis-necessary for the foundation of America and one still used to justify imperialist policies at home and abroad. While the thesis emerges from a specifically American context, its cultural and discursive features proliferate beyond geopolitical boundaries. The mythological crossing of the frontier to conquer and tame the wild landscape allows for the foundational myth of America to remain intact. However, the frontier is not the same as the wild landscape and is a space that exists as neither urban nor rural. The frontier itself cannot be conquered, only crossed. To conquer the frontier is to render it a place and thus as something that cannot be crossed. Thus it must always remain in place-or rather, in space-or else the myth of America would disintegrate. America cannot be America without its frontier.

As the dual processes of urbanization and the taming of the wild rural increases, the frontier between rural and urban begins to disintegrate. As people move out of the rural areas and into cities, the rural becomes its own frontier, demarcating the 
boundary not between urban and rural, but between cities. The rural is no longer a place transformed into a space, but becomes a pure space of movement, a frontier that exists only to be crossed. The stories we tell about the rural are thus stories of its passage, its seeming pastness or its incidental quality. The rural, shaped by the frontier, starts to become anecdotal -incidental, unpredictable and undecidable.

\section{Anecdotal Space}

Rural space is anecdotal space. By this I mean two things: First, we can think of rural space through short personal stories of rural life. My Prairie Homés use of short anecdotes about Spoon's prairie past approaches rural space this way. Second, to think of rural space as anecdotal space is to think certain iterations of it as beside the point and to be passed over. This is not to say that rural space is irrelevant, but rather that it is neither here nor there. I draw here from the way Meghan Morris utilizes the term in her book Identity Anecdotes. To be anecdotal is to be beside the point, though not so far beside the point that it is relegated to the margins. It is not "here" in the centre nor "there" in the margins. "Marginalized," Morris suggests, "is too plaintive a term for this situation" (2006: 2). Morris identifies a kind of mournfulness to marginality, or a sense that to be marginalized demands a kind of pity derived from the fact that a marginalized identity can never be set aside. To be marginal is to never be let in, to never be so close to the point that you can spatially conceive of yourself as beside it. Anecdotal identities, in contrast, can be let in and can have "full involvement in that economy at the simple cost of setting aside certain knowledges and concerns, which are localized by this transaction" ( 2 emphasis original). An anecdotal identity is not marginal in the sense that it has the privilege of being able to be put aside in a given exchange. An anecdotal identity is often simply forgotten.

It is Morris's own position as an Australian that causes her to contemplate this kind of anecdotal identity. To be Australian is to be anecdotal. Australians are not marginalized, since by virtue of a number of colonial privileges they can be thought within the zone of a white English-speaking cultural majority. But they are not part of that majority since, unlike Canada, the United States, or Great Britain, Australia is "deemed unimportant or eccentric within [that] economy of intellectual exchange" (2). Geographically located in the global south, Australia can easily be thought as extraneous to this Euro-American cultural paradigm. But the anecdotal identity, despite its cultural closeness to this centre, and despite how frequently it is simply forgotten, can "emerge, in hapless moments of communicative failure, as floundering non-sequiturs, obscure phrasings, flares of irritation, or quaint stories and jokes" (2). Anecdotal identities can break through the surface as unintended and embarrassing ruptures, or they can just happen with little fanfare. Because of its proximity to more centrally located identities there is always a possibility of it erupting through and causing a localized disruption in our relations. 
To think of rural space anecdotally is thus to think of its proximity to other more central spatial configurations, and thus to think of that frontier between the anecdote and a given situation. I am thinking of space here in the same terms that Morris thinks of identity. This does not mean, however, that the rural is the anecdote to the centre of the city, the most obvious spatial configuration that is often posited against the rural. Morris is not interested in such broad theoretical approaches that see the anecdote as a minoritized position that challenges and disrupts "grand narratives" (20). Indeed, it would be foolish to see an anecdotal rural as opposed to a grand narrative of the urban. According to Michael Woods, rurality is quite simply unthinkable without the urban. The rural emerged conceptually at the same time settlements were becoming more common and there was a need to demarcate the 'out there' of the country from the 'in here' of the town (2011: 17). Jacques Derrida argues that the outside of a concept is necessarily its inside. Thus the rural cannot be outside nor can the city be inside since each is necessary in the constitution of the other. There is no outside/inside, centre/margin, only concepts whose meaning is constantly deferred, bearing the trace of its other ([1967] 1998: 35).

Indeed, the essence - such a Platonic term can only be mobilized alongside Derrida ironically — of the anecdote is its constant deference. The anecdotal is always deferred, set aside, displaced. The anecdote is Derrida's différance, its undecidability the very thing that makes the anecdote thinkable as such. To be anecdotal "may simply mean taking advantage of proximity to hazard an initiative ("what do you make of this story?'), to accept the bother of not having a clue what might come next, and to make room in time for history to happen" (Morris 2006: 22). The anecdote is not the other to the grand narrative or to the centre; it is instead the very inability to be uncertain about your position and what might happen when you take the privilege of closeness as an opportunity to take a chance.

If we were to insist on holding onto the anecdotal rural as having any possibility of disrupting some grand narrative of the city and of modernity, it comes not from its position as a marginal outside but through its very closeness to and within the idea of the city itself. The city may indeed occupy a privileged locus of analysis because of its centrality to modernity, but it only remains intelligible because of the differrance of the rural itself. Judith Butler, if we extrapolate her arguments about identity into space, would perhaps then see this proximity and différance of the rural as a political opportunity, a way for the rural to intervene in the normative hegemony of the city (Butler [1990] 2006: 22). If we think of the city as having margins, just as identities do, then the rural would be "excess, something more" and thus perhaps something that can constitute a challenge to the seeming unity of the city (Hall 1996: 5). However, for Stuart Hall this kind of intentional politics of proximity remains untenable because, if we think of the rural as a kind of spatial identity, "[I] dentities are $[\ldots]$ points of temporary attachment" (6). If we attach to the rural as an identity, it can only be for a moment, and the effects of this moment, because of the deferential and differential quality of identity, cannot be predicted or controlled. 
By thinking the rural as not just différance but as anecdotal, I am undercutting such an idealistic and unproductively utopian politics that sees the rural as an always-resistive space. Such a politics would suggest that the intent of the rural could be controlled, as if every instantiation of the rural within the life of the city would automatically lead to some kind of oppositional, resistive, or disruptive politics. Such an understanding of différance is mistaken, and, as Rand forcefully argues, paradoxically defers the very deferential quality of différance. The différance of language cannot be wielded as an oppositional tactic since it is by its very nature undecidable and unpredictable, and thus entails a certain engagement with risk (Rand 2014: 168-9). We cannot ever be certain of the effect that the words we speak will have. As such, there is always a gap in language, a gap that cannot be bridged by intent alone. Words can be unpredictable and may have unpredictable effects. Morris's articulation of the anecdote as that which erupts without warning, and whose affects range from humor to irritation, is exactly the kind of undecidable and unpredictable speech act that Rand suggests we must risk. Anecdotes of the rural, or anecdotes that betray rurality, may abound in the city, but they can never be mobilized in an oppositional way. We must simply be content to let them arise and let their effects play out.

That the anecdotal rural cannot be wielded as a political tool, however, does not necessarily mean that it is apolitical. The context within which Rand critiques the oppositional view of différance is queer academic and activist rhetoric. Given her investments in a radical queer politics and world making practice that can disrupt hegemonic forms of culture and capital, she is not interested in divesting queerness of political possibility. She reclaims queer, as many before her have done, to name not some resistive or oppositional politics, but to name that very gap in language between authorial intent and textual effects. She encourages us to thus see queer as that which is undecidable and unpredictable. For her, queerness as undecidability is a far more productive approach to the formation of queer life because it quite simply allows for more possibilities than a deterministic and oppositional view of queerness. In short, the unpredictability of effects opens up the possibility of alternative worlds unthinkable within a strict centre/margin, dominant/oppositional framework.

In the same way that Rand reclaims queer in the name of undecidability, I want to reclaim the rural as queer, as Rand articulates it. The rural is an undecidable queer space that opens up possibilities for queer worlds. The anecdotal rural can thus be political insofar as it is undecidable. I am taking a stronger political position than Morris, who sees anecdotes as a more benign way of speaking. When the anecdotal rural emerges within the context of the city, it could have the effect of reconfiguring the entire relation in a given context, or it could appear as a momentary nuisance. Either way, it is the very fact that the rural is undecidable that allows it to be thought within the city in the first place and thus allows it to potentially become a site of diverse political actions. 
The anecdotal rural is thus doubly queer because both the anecdote and the rural are undecidable spaces. Rand's book is devoted to arguing how a number of rhetorical forms - history, polemic, theory, comedy — are queer by virtue of their undecidability. To Rand's list I add anecdotes. Their effects are unpredictable, and, like the polemic in particular, they are often seen as the shadowy underbelly of that academic stalwart quantitative data. So too can rural space be conceptualized as queer: it cannot be pinned down and is an unstable and unpredictable configuration that at once names the gap between spaces (the frontier) and also the very lack of a gap that the porous nature of the frontier establishes (the bridge). The very possibility that the rural may in fact be queer belies decades of queer history and theory that situate queerness as a particularly urban phenomenon. To see rural space as both an anecdote and as queer is to invigorate it with political possibility and as a way to challenge the urban hegemony of queer theory and activism.

\section{The Then and There of Home}

As I alluded to in my introduction, rural spaces are also queer spaces because queers often call rural spaces home. For Rae Spoon, the self-described "gender retired" subject of My Prairie Home (Spoon 2014), the rural is a queer home. Though Spoon grew up in Calgary, Alberta, the documentary makes clear that their home lays outside of such urban confines. Spoon's constant reflections on their family and why they always tour the Prairies provide My Prairie Home with an empathetic backbone as they paint a picture of two competing homes: an urban Christian evangelical household dominated by their abusive father and a rural home at the Athabasca Glacier in the Rocky Mountains. The "prairie home" of the title ambiguously refers to both, despite the fact that neither space is technically prairie in any material sense, though Athabasca would most certainly be rural. Images of prairie landscapes abound in the film, and their wide expanses connect these two competing homes: before Spoon can get to Athabasca, they must leave Calgary and travel across the Prairies. The Prairies become a frontier, an open space of wilderness that must be crossed before Spoon can reach home in either of its formations.

Home-indeed any space - is bound by time. That is what leads Doreen Massey to articulate space as space-time. The logic of crossing the frontier, for example, is not simply the logic of moving through space, but also the logic of moving through time. To move through space is to move through time; hence, time is what marks the boundaries between spaces, and between spaces and places. In My Prairie Home the prairie frontier is the exemplar of space-time, shot always in motion from inside a moving vehicle. The prairie becomes time, a symbol of its passage between homes. Home is then literally bounded by time, the frontier/crossing marking the boundaries between home.

If the spatio-temporal logic of the rural prairie in My Prairie Home, and thus the spatio-temporal logic of the frontier, is passage, what is the spatio-temporal logic of home? In other words, when and where is home? For Massey, home always 
exists in the past as an indeterminate spatial trajectory-like the prairie, it too is a space. The when of home is then and the where of home is nowhere. If home were a definitive there, for Massey, then it would be a place, a static and stable configuration of objects. However, thinking of home as a place forces us to admit that "we can never go 'home', or at any rate we cannot do so if we imagine home as an enduring site from whence we came" (Massey 2000: 230). Home is not an enduring site or a place for Massey, but a space configured by movement and by competing trajectories that can never be returned to. To think of home as an enduring site is a nostalgic drive that rips home out of time and out of space and "robs it of a history" (230). Home has a context; it is an indeterminate trajectory of moments that coalesce around the configuration of objects we call home. At one moment, your family may occupy that space, but in another it could be a different family. In that other moment, the-place-where-home-was is no longer your home but is simply another configuration of objects. Home is thus not a configuration of objects, a static place that can be named and pointed at, but a then that always moves. Home is a nowhere for Massey, an indeterminate space between places that exist only in the past and can never be returned to.

For the most part, this spatio-temporal logic works and accurately captures the spirit of Spoon's relationship to their home. Spoon returns to the Prairies, a rural configuration of objects, however, the space has changed and is not the same as it was when they were growing up. Instead of returning to Calgary to find an abusive father, home is now a source of musical inspiration. In one scene, Spoon returns home and talks with their high school girlfriend Sandia. As Spoon and Sandia recall some of their memories together, they begin to reenact some of those moments as adults, culminating in a recreation of their high school prom. Viewers are led to believe that the high school reenactments take place in is the high school Spoon and Sandia attended, if only because of the correlation between Spoon's stories and the images that appear on screen. However, in a public interview after a screening of My Prairie Home in St. John's, Newfoundland, Spoon (2014) admits that the high school they shot the scene in was not actually their high school, but a stand-in since their actual high school would not grant them permission to film. In this case, not only has the spatial configuration of home and high school changed, since the same bodies do not walk those halls, but also the supposedly stable configuration of objects that mark the high school as a place. In My Prairie Home, not only has the space of home changed but also the place.

Place is thus not as stable as de Certeau or Massey would have it, at least not in a documentary film that would substitute one place for another without any textual indication that it has happened. As space-time and place-time, home is an indeterminate zone, not simply a then and a nowhere, but a then and a there whose referents are always indeterminate and undecidable. "There", as a marker for place, does not point at a determinate configuration of objects, but only to that which signifies those objects. Place is nothing but a sign referring to other signs. The 
concrete materiality that characterizes place for Massey and de Certeau is just a shifter of meaning whose signifieds can be torn out of context and replaced with something else.

Massey's conceptualization of space-time misses the indeterminacy not only of place, but also of time. To be "then" is not simply to be in the past- "I was living at home then"- but it is also to be in the future- "I lived at home and then I lived on my own." "Then" is an indeterminate temporality that holds within itself both a sense of that which already happened and that which happens next. José Esteban Muñoz mobilizes this indeterminacy to think of a "queer futurity":

The present is not enough. It is impoverished and toxic for queers and other people who do not feel the privilege of majoritarian belonging, normative tastes, and 'rational' expectations. [...] Let me be clear that the idea is not simply to turn away from the present. One cannot afford such a maneuver, and if one thinks one can, one has resisted the present in favor of folly. The present must be known in relation to the alternative temporal and spatial maps provided by a perception of past and future affective worlds. (2009: 27)

For Muñoz, the past is mobilized in relation to the present in the service of imagining a queer utopian future not beholden to the pragmatic and normative politics of the present. To challenge the normative passions of the present, we must be able to think then and there and not here and now. We must conceptualize of alternative worlds- "temporal and spatial maps"- that are not simply nostalgic longings for the past or naive visions of the future, but rather mobilizations of a performative space-time, one that sees the past as well as the future as not "being static and fixed" but instead as one that "does things" (28). Queer futures are thus a kind of then and there, an indeterminate temporality of movement.

As we have seen with space, place, anecdotal identities, and home, time too can be queerly indeterminate. Spoon's prairie home is a queer then and there, its rurality the site of a radical queer future. This queer time is structured both for Muñoz and in My Prairie Home by the anticipatory affective structures of hope and fear. Instead of positing the rural home's dominant affect as fear-both fear of abuse from a phobic parent but also the phobia of the parent-as metronormativity is fond to do, the queer version of home presented by My Prairie Home is filled with hope. Hope, like fear, Muñoz says, anticipates a future (3). But unlike fear, whose affective strength can stop queers from acting, hope can be mobilized as a "critical affect and methodology" for thinking beyond the present (4). Both hope and fear may be anticipatory, but only hope anticipates a future better than the present we live in now. By conceptualizing the rural as a site of fear, metronormativity limits the affective and discursive possibilities for queer life to the realm of the urban. By anticipating a better future, hope can provide a way to think of new possibilities for queer life beyond the urban and within the rural. 
The two visions of home bounded by prairies allow for the possibility of a queer future in a rural space. The rural home of the Athabasca Glacier, unlike the urban Calgary home, is not simply bounded by time, but is characterized by time. But unlike the time of the prairie frontier, which is a fast time, a time characterized by the quick speed of the passing prairie landscape, the glacier is a slow time. The images of the glacier are relatively still compared to those of the prairies, but we still see the glacier melting, water dripping from the ice, an indication of the passage of time. The Athabasca Glacier is caught in a time paradox: on the one hand, it is a frozen memory of our historical past, but on the other, its continual melting indicates a future where it will be gone. It is perhaps no coincidence that the glacier is Spoon's affective home: when people ask Spoon where they are from, the answer they give is often Calgary but the place they feel is the glacier. At the glacier they feel something other than the fear found in the urban. They feel the hopeful possibility that rural life can imagine for queers; the rural is a possible place where they can become without fear. Thus, contrary to dominant narratives of queer and trans life that see the urban environment as filled with hope and possibility and the rural as phobic and destructive, it is a rural space that provides Spoon with the hope and possibility of becoming.

Such becoming, though, is not a result of a return to an idealized and idyllic pastoral rural past. This past is a queerly performative past that not only does things to the present - as the dripping water does to the environment - but also a theatrical past where, drawing on the performance aspect of Butler's performative theory of identity, musical performance queers rural spaces. A number of staged musical performances occur throughout the documentary, but the two in particular that bookend the film speak most clearly to their queer performativity. The first performance, which opens the film, has Spoon in a small town diner, walking through the aisles with their guitar singing about how when they were young they dreamed of being a cowboy. Instead of performing in a static location in the diner, or simply just sitting and eating their meal, Spoon moves through the space, queering what was an otherwise everyday space of the diner. The other scene I have in mind comes near the end of the film when Spoon is singing in a forest while people wearing deer masks dance and pose in tableaux. This scene in the forest leads into the final scene of Spoon at the Athabasca Glacier remarking about how it is more of a home to them than Calgary. It is at this rural home, a home outside of the phobic confines of the city, that Spoon is able to express their queerness to its full potential. The rural in My Prairie Home is queer.

But the rural is not queer because of the way it seemingly resists the phobia of the urban. The rural was never intended to be a radical queer site of resistance. Instead, the rural is queer because it is an anecdotally undecidable space of a then and there, a rural past and a possible future called into being through Spoon's rural anecdotes and performances. The queer rural-and the rural queer-is not a marginalized space but a space that cannot be decided or predicted. At some moments it may 
hold within it the destruction of life. At others, it holds only the possibility of a new life, of a new world that cannot be predicted or controlled, but a world that allows for the flourishing of life in all of its queer forms.

\section{References}

Butler, Judith. (1990) 2006. Gender Trouble: Feminism and the Subversion of Identity. London and New York: Routledge.

de Certeau, Michel. 1984. The Practice of Everyday Life. Translated by Steven Rendall. Berkeley: University of California Press.

Derrida, Jacques. (1967) 1998. Of Grammatology. Translated by Gayatri Chakravorty Spivak. Corrected edition. Baltimore: Johns Hopkins University Press.

Halberstam, Judith [Jack]. 2005. In a Queer Time and Place: Transgender Bodies, Subcultural Lives. New York and London: New York University Press.

Hall, Stuart. 1996. “Introduction: Who Needs 'Identity'?” In Questions of Cultural Identity, edited by Stuart Hall and Paul du Gay, 1-17. London: Sage.

Rand, Erin J. 2014. Reclaiming Queer: Activist \& Academic Rhetorics of Resistance. Tuscaloosa: University of Alabama Press.

Massey, Doreen. 2000. "Travelling Thoughts." In Without Guarantees: In Honour of Stuart Hall, edited by Lawrence Grossberg, Angela McRobbie, and Paul Gilroy, 224-232. London: Verso.

McMullan, Chelsea. My Prairie Home. DVD. Directed by Chelsea McMullan. Montreal: National Film Board of Canada, 2014.

Morley, David. 2000. Home Territories: Media, Mobility and Identity. London: Routledge. Morris, Meghan. 2006. Identity Anecdotes: Translation and Media Culture. London: Sage. Muñoz, José Esteban. 2009. Cruising Utopia: The Then and There of Queer Futurity. New York: New York University Press.

Spoon, Rae. 2014. "Q\&A with Rae Spoon.” Public Interview at Scene \& Heard Film Industry Conference, St John's, NL, March 8, 2014.

Woods, Michael. 2011. Rural. London: Routledge. 